\title{
Salinity tolerance in Senna macranthera (DC. ex Collad.) H. S. Irwin \& Barneby seeds with sodium nitroprusside (SNP) promoted by cyanide ${ }^{1}$
}

\author{
Aparecida Leonir da Silva ${ }^{2 *}$, Daniel Teixeira Pinheiro ${ }^{3}$, Eduardo Euclydes de Lima \\ e Borges ${ }^{4}$, Laércio Junio da Silva ${ }^{3}$, Denise Cunha Fernandes dos Santos Dias ${ }^{3}$
}

\begin{abstract}
Studies show the positive effect of the nitric oxide donor in the seed germination process. However, there are no precise reports about which compound present in sodium nitroprusside would cause these effects in seeds under salt stress. The aim of this study was to evaluate the effects of SNP on germination of Senna macranthera seeds under salt stress. The osmotic potentials of $-0.3,-0.4$, and $-0.5 \mathrm{MPa}$ of $\mathrm{NaCl}$ were used, as well as the concentration of $100 \mu \mathrm{M}$ of sodium nitroprusside, inactive sodium nitroprusside, and ferrocyanide. The sodium nitroprusside in germination was applied before, during, and after salt stress. Germination rate, germination speed index, percentage of normal seedlings, and seedling development components were evaluated. The treatments that proved to be more promising in recovery of germination under salt stress are -0.4 MPa together with SNP; -0.4 MPa together with inactive SNP; - $0.5 \mathrm{MPa}$ together with SNP and -0.5 MPa together with inactive SNP. Effects similar to those brought about by the sodium nitroprusside treatment were also observed in the treatments with inactive sodium nitroprusside and ferrocyanide, indicating that the effects observed were related to release of the cyanide present in the sodium nitroprusside.
\end{abstract}

Index terms: ferrocyanide, $\mathrm{NaCl}$, salt stress.

\section{Tolerância à salinidade em sementes de Senna macranthera (DC. ex Collad.) H.} S. Irwin \& Barneby com nitroprussiato de sódio (SNP) promovida pelo cianeto

\begin{abstract}
RESUMO - Estudos demonstram o efeito positivo do doador de óxido nítrico $(\mathrm{ON})$ no processo germinativo de sementes. Contudo, não há relatos precisos sobre qual composto presente no nitroprussiato de sódio (SNP) que causaria esses efeitos em sementes sob estresse salino. O trabalho teve como objetivo avaliar os efeitos do SNP na germinação de sementes de Senna macranthera sob estresse salino. Foram utilizados os potenciais osmóticos de -0,3, -0,4 e -0,5 $\mathrm{MPa}$ de $\mathrm{NaCl}$ e a concentração de $100 \mu \mathrm{M}$ de SNP, SNP inativo e ferrocianeto. A aplicação do SNP na germinação foi feita antes, concomitantemente e depois do estresse salino. Foram avaliados a porcentagem de germinação, o índice de velocidade de germinação, porcentagem de plântulas normais e componentes do desenvolvimento das plântulas. Os tratamentos mais promissores na recuperação da germinação sob estresse salino são $-0.4 \mathrm{MPa}$ concomitantemente com SNP; $-0.4 \mathrm{MPa}$ concomitantemente com SNP inativo; - 0.5 MPa concomitantemente com SNP and -0.5 MPa concomitantemente com SNP inativo. Efeitos similares aos provocados pelo tratamento com SNP também foram constatados nos tratamentos com SNP inativo e ferrocianeto, indicando que os efeitos observados estariam relacionados à liberação do cianeto presente no SNP.
\end{abstract}

Termos para indexação: ferrocianeto, $\mathrm{NaCl}$, estresse salino.

\section{Introduction}

Senna macranthera (DC. ex Collad.) H. S. Irwin \&
Barneby is a tree specie that belongs to the family FabaceaeCaesalpinioideae. Due to its ornamental characteristics and small size, it is used in landscaping and is classified as a

${ }^{4}$ Departamento de Engenharia Florestal, Universidade Federal de Viçosa, 36570-000 - Viçosa, MG, Brasil.

*Corresponding author < aparecidaleonir@gmail.com>
${ }^{1}$ Submitted on 05/09/2018. Accepted for publication on 06/16/2018. ${ }^{2}$ Departamento de Biologia Vegetal, Universidade Federal de Viçosa, 36570000 - Viçosa, MG, Brasil.

${ }^{3}$ Departamento de Fitotecnia, Universidade Federal de Viçosa, 36570-000 Viçosa, MG, Brasil. 
pioneer species with rapid growth, recommended for planting in degraded areas (Lorenzi, 2000).

Germination is a fundamental stage in the establishment of plants in the field and can be altered by the environment determining when and how the seeds germinate or die (Long et al., 2015). In this context, salinity is among the factors that at certain levels may affect radicle protrusion, limit initial development of the seedling, and, in more extreme cases, result in seed or seedling death. Salt stress is among the factors that most lead to reduction and delay in the seed germination process, and studying the mechanisms involved in this process is of great importance for the purpose of developing adequate measures for attenuating these effects (Zheng et al., 2009; Fan et al., 2013).

Salinity affects germination not only through hindering water absorption due to reduction in the osmotic potential of the medium, but also through facilitating entry of toxic amounts of ions $\left(\mathrm{Na}^{+}\right.$and $\left.\mathrm{Cl}^{-}\right)$in seeds during soaking (Simaei et al., 2012).

Reduction in water availability affects both seed hydration and cell metabolism because water constitutes the matrix responsible for most biochemical and physiological processes that result in primary root protrusion (Bewley et al., 2013). Fan et al. (2013) emphasize the need and importance of more studies to understand the physiological mechanisms involved in germination of seeds under salt stress and develop adequate measures to mitigate the negative effects of salinity in this process.

Among the agents that favor germination under stress, nitric oxide (NO) has shown prominence in stimulating this process for many species. NO is a free radical produced from L-arginine, a toxic, inorganic, colorless gas with seven nitrogen and eight oxygen electrons. It is one of the most important mediators of intracellular and extracellular processes (Dusse et al., 2003) and recently has been considered a hormone (Santner and Estelle, 2009). NO is considered an important endogenous plant bioactive signaling molecule involved in many process including seed germination, plant growth, photosynthesis, antioxidant metabolism and others (Mostofa et al., 2015; Kaya et al., 2015; Ahmad et al., 2016). Sodium nitroprusside (SNP) is the most often NO donor used in germination studies due to its capacity to release this molecule when it is induced by the presence of light (Wang et al., 2002). However, some authors contest that the positive effect on germination caused by NO donors is in fact from the NO, as reported in Arabidopsis seeds, for which SNP was used to overcome dormancy. The authors found that this effect was due to the cyanide formed by the SNP (Bethke et al., 2006). In Clitoria ternatea and Rhyncosia minima seeds, there was also an increase in germination with the use of cyanide (Mullick and Chatterji, 1967). The effects of NO on germination under salt stress have been investigated in species such as mustard (Khan et al., 2012), cucumber (Fan et al., 2013) and Arabdopsis (Lin et al., 2013) and others. Nevertheless, there are no reports regarding which compound present in the SNP would cause these effects in seeds under salt stress. In light of the foregoing, the aim of this study was to evaluate the effects of sodium nitroprusside (SNP) on germination of $S$. macranthera seeds under salt stress.

\section{Material an Methods}

S. macranthera seeds were collected in the region of Viçosa, Minas Gerais, Brazil, and placed in cold storage at $5{ }^{\circ} \mathrm{C}$ with $60 \%$ relative humidity. Before carrying out the trials, the seeds were mechanically scarified with number 100 sandpaper on the side opposite the hilum and then treated with CAPTAN fungicide at $0.2 \%\left(150 \mathrm{~g} .100 \mathrm{Kg}^{-1}\right.$ of seeds).

Three concentrations of $\mathrm{NaCl}$, osmotic potentials -0.3 , -0.4 , and $-0.5 \mathrm{MPa}$, that caused reduction of about $50 \%$ in seed germination were selected, as well as SNP and ferrocyanide concentrations $(100 \mu \mathrm{M})$ that was proved to be effective in recovery seeds from stresses (Silva et al., 2015).

The period of 24 hours ( $30 \%$ moisture in seeds) was defined through imbibition curves as the hydration time adequate for application of the treatments with SNP.

Experiments were then conducted to determine the effects of SNP on germination of $S$. macranthera seeds under salt stress. Four replications of 50 seeds were used. The seeds were placed to germinate in a seed incubator at $25^{\circ} \mathrm{C}$ with an 8 hour photoperiod for 7 days. During this time, SNP, inactive SNP (48 hours of exposure to light), sodium ferrocyanide $\left(\mathrm{Na}_{4} \mathrm{Fe}(\mathrm{CN})_{6}\right)$, and pure water (control) were applied in different periods as described below. In all treatments, the seeds were kept in rolls of paper towel moistened with a volume of solution or of water equal to 2.5 times the weight of the dry paper under the conditions described above.

\section{Application before salt stress}

Seeds were placed to soak in paper toweling moistened with the solutions of $100 \mu \mathrm{M}$ SNP (Silva et al., 2015), 100 $\mu \mathrm{M}$ ferrocyanide, $100 \mu \mathrm{M}$ inactive SNP, or with water for 24 hours. After that, the seeds were placed in rolls of paper toweling moistened with $\mathrm{NaCl}$ solution at the osmotic potentials of $-0.3,-0.4$, or $-0.5 \mathrm{MPa}$, previously defined by Silva et al. (2015).

\section{Application after salt stress}

The seeds were placed in paper towel moistened with $\mathrm{NaCl}$ solution at the osmotic potentials of $-0.3,-0.4$, and -0.5 MPa for 24 hours. They were then washed in distilled water 
to remove excess salt and transferred to rolls of paper towel moistened with $100 \mu \mathrm{M}$ SNP, $100 \mu \mathrm{M}$ ferrocyanide, $100 \mu \mathrm{M}$ inactive SNP, and water (control).

\section{Application together with salt stress}

The seeds were placed to germinate in paper towel moistened with $\mathrm{NaCl}$ solutions at $0.3,-0.4$, or $-0.5 \mathrm{MPa}$ with the addition of $100 \mu \mathrm{M}$ SNP, $100 \mu \mathrm{M}$ ferrocyanide, and 100 $\mu \mathrm{M}$ inactive SNP solutions and also in water (control).

All the treatments were evaluated daily (for seven days) regarding the number of germinated seeds (with primary root of at least $2 \mathrm{~mm}$ length), and the percentage of germinated seeds was calculated. The percentage of normal seedlings was also evaluated. On the seventh day after sowing, the percentage of germination and the percentage of normal seedlings were calculated. The germination speed index (GSI) was calculated from the daily data. At the end of the germination tests, the shoot length (SL) and the root system length (RL) were measured with the aid of a caliper rule, and the results were expressed in millimeters per seedling. Determinations of shoot dry matter (SDM) and root dry matter (RDM) were performed by the laboratory oven method with forced air at
$70{ }^{\circ} \mathrm{C}$ until reaching constant weight.

Germination, normal seedlings, GSI, length and dry matter of seedlings were analyzed in a completely randomized design (CRD) with 19 treatments: control $\left(\mathrm{H}_{2} \mathrm{O}\right) ; \mathrm{H}_{2} \mathrm{O} \rightarrow-0.3$ $\mathrm{MPa} ; \mathrm{H}_{2} \mathrm{O} \rightarrow-0.4 \mathrm{MPa} ; \mathrm{H}_{2} \mathrm{O} \rightarrow-0.5 \mathrm{MPa} ; \mathrm{SNP} \rightarrow-0.3 \mathrm{MPa}$; $\mathrm{SNP} \rightarrow-0.4 \mathrm{MPa}$; SNP $\rightarrow-0.5 \mathrm{MPa}$; ferrocyanide $\rightarrow-0.3 \mathrm{MPa}$; ferrocyanide $\rightarrow-0.4 \mathrm{MPa}$; ferrocyanide $\rightarrow-0.5 \mathrm{MPa}$; inactive $\mathrm{SNP} \rightarrow-0.3 \mathrm{MPa}$; inactive $\mathrm{SNP} \rightarrow-0.4 \mathrm{MPa}$; inactive $\mathrm{SNP} \rightarrow$ -0.5 MPa; SNP; ferrocyanide; inactive SNP; -0.3 MPa; -0.4 $\mathrm{MPa}$; and -0.5 MPa with four replications. Each experimental unit was composed of 50 seeds. The data were subjected to analysis of variance. The means obtained in the treatments were grouped by the Scott-Knott test at 5\% probability.

\section{Results and Discussion}

In the different treatments with soaking in SNP, inactive SNP, and ferrocyanide, followed by transfer to the salt solutions of $-0.3,-0.4$, and $-0.5 \mathrm{MPa}$ (Table 1 ), the highest percentages of germination were found in the treatments with soaking in ferrocyanide and inactive SNP, statistically differing from the others (Table 1). There was no seedling

Table 1. Germination (G) (\%), germination speed index (GSI), normal seedlings (NS) (\%), shoot length (SL) (mm), root length (RL) (mm), shoot dry matter (SDM) (mg), and root dry matter (RDM) (mg) in scarified seeds of $S$. macranthera placed to germinate in different treatments (SNP, inactive SNP, and ferrocyanide) before the application of salt stress $(0.3,-0.4$, and $-0.5 \mathrm{MPa})$ at $25^{\circ} \mathrm{C}$.

\begin{tabular}{|c|c|c|c|c|c|c|c|}
\hline Treatment & G & GSI & NS & SL & RL & SDM & RDM \\
\hline $\mathrm{H}_{2} \mathrm{O} \rightarrow-0.3 \mathrm{MPa}$ & $82 \mathrm{c}$ & $9.11 \mathrm{~d}$ & $30 \mathrm{~d}$ & $12.21 \mathrm{~b}$ & $23.12 \mathrm{c}$ & $32.46 \mathrm{a}$ & $3.25 \mathrm{~b}$ \\
\hline $\mathrm{H}_{2} \mathrm{O} \rightarrow-0.4 \mathrm{MPa}$ & $77 \mathrm{~d}$ & $7.49 \mathrm{f}$ & $0 \mathrm{e}$ & $0.00 \mathrm{e}$ & $0.00 \mathrm{e}$ & $0.00 \mathrm{c}$ & $0.00 \mathrm{e}$ \\
\hline $\mathrm{H}_{2} \mathrm{O} \rightarrow-0.5 \mathrm{MPa}$ & $60 \mathrm{f}$ & $5.09 \mathrm{~h}$ & $0 \mathrm{e}$ & $0.00 \mathrm{e}$ & $0.00 \mathrm{e}$ & $0.00 \mathrm{c}$ & $0.00 \mathrm{e}$ \\
\hline $\mathrm{SNP} \rightarrow-0.3 \mathrm{MPa}$ & $83 \mathrm{c}$ & $9.60 \mathrm{c}$ & $30 \mathrm{~d}$ & $13.78 \mathrm{~b}$ & $26.76 \mathrm{c}$ & $31.46 \mathrm{a}$ & $3.28 \mathrm{~b}$ \\
\hline $\mathrm{SNP} \rightarrow-0.4 \mathrm{MPa}$ & $79 \mathrm{~d}$ & $8.14 \mathrm{e}$ & $4 \mathrm{e}$ & $4.73 \mathrm{~d}$ & $11.58 \mathrm{~d}$ & $14.33 \mathrm{~b}$ & $1.75 \mathrm{~d}$ \\
\hline $\mathrm{SNP} \rightarrow-0.5 \mathrm{MPa}$ & $60 \mathrm{f}$ & $5.14 \mathrm{~h}$ & $0 \mathrm{e}$ & $0.00 \mathrm{e}$ & $0.00 \mathrm{e}$ & $0.00 \mathrm{c}$ & $0.00 \mathrm{e}$ \\
\hline Ferrocyanide $\rightarrow-0.3 \mathrm{MPa}$ & $88 \mathrm{~b}$ & $10.05 \mathrm{c}$ & $31 \mathrm{~d}$ & $12.66 \mathrm{~b}$ & $25.46 \mathrm{c}$ & $30.88 \mathrm{a}$ & $3.32 \mathrm{~b}$ \\
\hline Ferrocyanide $\rightarrow-0.4 \mathrm{MPa}$ & $86 \mathrm{~b}$ & $8.40 \mathrm{e}$ & $4 \mathrm{e}$ & $8.60 \mathrm{c}$ & $17.78 \mathrm{c}$ & $24.88 \mathrm{a}$ & $2.94 \mathrm{~b}$ \\
\hline Ferrocyanide $\rightarrow-0.5 \mathrm{MPa}$ & $73 d$ & $6.41 \mathrm{~g}$ & $0 \mathrm{e}$ & $0.00 \mathrm{e}$ & $0.00 \mathrm{e}$ & $0.00 \mathrm{c}$ & $0.00 \mathrm{e}$ \\
\hline Inactive $\mathrm{SNP} \rightarrow-0.3 \mathrm{MPa}$ & $90 \mathrm{~b}$ & $12.26 \mathrm{~b}$ & $43 \mathrm{c}$ & $14.45 \mathrm{~b}$ & $31.94 \mathrm{~b}$ & $29.69 \mathrm{a}$ & $3.97 \mathrm{a}$ \\
\hline Inactive $\mathrm{SNP} \rightarrow-0.4 \mathrm{MPa}$ & $83 \mathrm{c}$ & $9.14 \mathrm{~d}$ & $5 \mathrm{e}$ & $12.55 \mathrm{~b}$ & $24.79 \mathrm{c}$ & $33.96 \mathrm{a}$ & $3.67 \mathrm{a}$ \\
\hline Inactive $\mathrm{SNP} \rightarrow-0.5 \mathrm{MPa}$ & $77 \mathrm{~d}$ & $7.24 \mathrm{f}$ & $0 \mathrm{e}$ & $0.00 \mathrm{e}$ & $0.00 \mathrm{e}$ & $0.00 \mathrm{c}$ & $0.00 \mathrm{e}$ \\
\hline SNP & $86 \mathrm{~b}$ & $6.64 \mathrm{~g}$ & $62 \mathrm{~b}$ & $35.66 \mathrm{a}$ & $34.91 \mathrm{~b}$ & $28.81 \mathrm{a}$ & $3.62 \mathrm{a}$ \\
\hline Ferrocyanide & $89 \mathrm{~b}$ & $7.28 \mathrm{f}$ & $72 \mathrm{a}$ & $36.26 \mathrm{a}$ & $36.69 \mathrm{~b}$ & $30.41 \mathrm{a}$ & $4.02 \mathrm{a}$ \\
\hline Inactive SNP & $96 \mathrm{a}$ & $14.21 \mathrm{a}$ & $67 \mathrm{a}$ & $37.02 \mathrm{a}$ & $43.03 \mathrm{a}$ & $31.56 \mathrm{a}$ & $4.43 \mathrm{a}$ \\
\hline Control (water) & $89 \mathrm{~b}$ & $13.58 \mathrm{a}$ & $70 \mathrm{a}$ & $34.74 \mathrm{a}$ & $41.30 \mathrm{a}$ & $34.80 \mathrm{a}$ & $4.68 \mathrm{a}$ \\
\hline - $0.3 \mathrm{MPa}$ & 67 e & $7.06 \mathrm{f}$ & $8 \mathrm{e}$ & $8.91 \mathrm{c}$ & $25.04 \mathrm{c}$ & $25.38 \mathrm{a}$ & $2.05 \mathrm{c}$ \\
\hline - $0.4 \mathrm{MPa}$ & $55 \mathrm{f}$ & $4.95 \mathrm{~h}$ & $0 \mathrm{e}$ & $0.00 \mathrm{e}$ & $0.00 \mathrm{e}$ & $0.00 \mathrm{c}$ & $0.00 \mathrm{e}$ \\
\hline$-0.5 \mathrm{MPa}$ & $36 \mathrm{~g}$ & $2.91 \mathrm{i}$ & $0 \mathrm{e}$ & $0.00 \mathrm{e}$ & $0.00 \mathrm{e}$ & $0.00 \mathrm{c}$ & $0.00 \mathrm{e}$ \\
\hline CV $(\%)$ & 5.43 & 6.06 & 20.11 & 20.94 & 25.91 & 31.62 & 33.21 \\
\hline
\end{tabular}

Mean values followed by the same letters in the columns do not differ among themselves by the Scott-Knott test at $5 \%$ probability. CV: coefficient of variation. 
formation in the pure salt stresses of -0.4, - $0.5 \mathrm{MPa}$ and in the treatments with soaking in water and transfer to the salt stresses of - 0.4 and - $0.5 \mathrm{MPa}$. However, in the other treatments with transfer to the osmotic potential of $-0.4 \mathrm{MPa}$, there was seedling formation (Table 1).

There was no formation of normal seedlings in any of the treatments with transfer to the salt stress of $-05 \mathrm{MPa}$. A significant increase was observed in percentage of normal seedlings in all the treatments (SNP, inactive SNP, ferrocyanide, and water) with transfer to the saline potential of $-0.3 \mathrm{MPa}$, compared to the pure salt stress of $-0.3 \mathrm{MPa}$ (Table 1 ).

The GSI decreased with the increase in salt concentration, and the highest values were obtained in the treatments with inactive SNP and in the control (water), which did not differ from each other. Among the treatments with transfer to the stresses, the highest values of GSI were obtained when the seeds were soaked in inactive SNP solution, followed by transfer to the salt stresses $(-0.3,-0.4$, and $-0.5 \mathrm{MPa})$.

The highest values of shoot length were observed in the treatments with inactive SNP, ferrocyanide, SNP, and control (water), which did not differ among themselves. However, the seedlings originated from seeds treated with inactive SNP exhibited the greatest shoot length and also root system length (Table 1).

Shoot dry matter of the seedlings originated from the treatments followed by salt stress of $-0.3 \mathrm{MPa}$ did not differ from pure salt stress $(-0.3 \mathrm{MPa})$. However, for the osmotic potential of $-0.4 \mathrm{MPa}$, higher mean values in the treatments with inactive SNP and ferrocyanide were observed, but they did not differ among themselves. The root dry matter was greater in the treatments with soaking in inactive SNP with transfer to the salt stress of $-0.4 \mathrm{MPa}$, statistically differing from the other treatments with transfer to the same potential (Table 1).

Comparing the soaking treatments at different osmotic potentials, followed by transfer to water, SNP, ferrocyanide, or inactive SNP, germination increased at the potentials of -0.3 and $-0.4 \mathrm{MPa}$, with transfer to inactive SNP (Table 2). There was seedling formation in all the treatments, which did not occur in the pure salt stress treatments of -0.4 and $-0.5 \mathrm{MPa}$ (Table 2). The germination speed index for the stresses of -0.3 and $-0.4 \mathrm{MPa}$ was greater in the treatments that were transferred to inactive SNP solutions and in the confirmation test with inactive SNP and the control (water). The germination speed indexes in all the treatments were greater than their respective pure salt stresses (Table 3).

Table 2. Germination (G) (\%), germination speed index (GSI), normal seedlings (NS) (\%), shoot length (SL) (mm), root length (RL) (mm), shoot dry matter (SDM) (mg), and root dry matter (RDM) (mg) in scarified seeds of S. macranthera placed to germinate in different treatments (SNP, inactive SNP, and ferrocyanide) after the application of salt stress $(0.3,-0.4$, and $-0.5 \mathrm{MPa})$ at $25^{\circ} \mathrm{C}$.

\begin{tabular}{lccccccc}
\hline \multicolumn{1}{c}{ Treatment } & $\mathrm{G}$ & GSI & NS & SL & RL & SDM & RDM \\
\hline$-0.3 \mathrm{MPa} \rightarrow \mathrm{H}_{2} \mathrm{O}$ & $80 \mathrm{~b}$ & $10.89 \mathrm{~b}$ & $62 \mathrm{a}$ & $29.67 \mathrm{~b}$ & $35.31 \mathrm{~b}$ & $33.41 \mathrm{a}$ & $3.83 \mathrm{~b}$ \\
$-0.4 \mathrm{MPa} \rightarrow \mathrm{H}_{2} \mathrm{O}$ & $85 \mathrm{~b}$ & $10.74 \mathrm{~b}$ & $56 \mathrm{a}$ & $25.00 \mathrm{c}$ & $29.50 \mathrm{c}$ & $34.37 \mathrm{a}$ & $3.40 \mathrm{c}$ \\
$-0.5 \mathrm{MPa} \rightarrow \mathrm{H}_{2} \mathrm{O}$ & $93 \mathrm{a}$ & $11.78 \mathrm{~b}$ & $65 \mathrm{a}$ & $28.06 \mathrm{~b}$ & $35.85 \mathrm{~b}$ & $30.89 \mathrm{~b}$ & $3.76 \mathrm{~b}$ \\
$-0.3 \mathrm{MPa} \rightarrow \mathrm{SNP}$ & $87 \mathrm{~b}$ & $11.38 \mathrm{~b}$ & $62 \mathrm{a}$ & $27.64 \mathrm{~b}$ & $30.95 \mathrm{c}$ & $34.17 \mathrm{a}$ & $3.75 \mathrm{~b}$ \\
$-0.4 \mathrm{MPa} \rightarrow \mathrm{SNP}$ & $82 \mathrm{~b}$ & $11.11 \mathrm{~b}$ & $63 \mathrm{a}$ & $27.71 \mathrm{~b}$ & $33.64 \mathrm{~b}$ & $32.13 \mathrm{a}$ & $3.88 \mathrm{~b}$ \\
$-0.5 \mathrm{MPa} \rightarrow \mathrm{SNP}$ & $83 \mathrm{~b}$ & $10.95 \mathrm{~b}$ & $67 \mathrm{a}$ & $25.71 \mathrm{c}$ & $33.43 \mathrm{~b}$ & $34.05 \mathrm{a}$ & $3.99 \mathrm{~b}$ \\
$-0.3 \mathrm{MPa} \rightarrow$ ferrocyanide & $87 \mathrm{~b}$ & $11.50 \mathrm{~b}$ & $65 \mathrm{a}$ & $23.32 \mathrm{c}$ & $27.56 \mathrm{~d}$ & $33.64 \mathrm{a}$ & $3.42 \mathrm{c}$ \\
$-0.4 \mathrm{MPa} \rightarrow$ ferrocyanide & $89 \mathrm{a}$ & $11.70 \mathrm{~b}$ & $67 \mathrm{a}$ & $25.33 \mathrm{c}$ & $30.77 \mathrm{c}$ & $34.59 \mathrm{a}$ & $3.90 \mathrm{~b}$ \\
$-0.5 \mathrm{MPa} \rightarrow$ ferrocyanide & $87 \mathrm{~b}$ & $11.50 \mathrm{~b}$ & $70 \mathrm{a}$ & $26.33 \mathrm{c}$ & $32.24 \mathrm{c}$ & $33.74 \mathrm{a}$ & $3.97 \mathrm{~b}$ \\
$-0.3 \mathrm{MPa} \rightarrow$ Inactive SNP & $92 \mathrm{a}$ & $13.47 \mathrm{a}$ & $74 \mathrm{a}$ & $30.80 \mathrm{~b}$ & $37.15 \mathrm{~b}$ & $34.17 \mathrm{a}$ & $3.86 \mathrm{~b}$ \\
$-0.4 \mathrm{MPa} \rightarrow$ Inactive SNP & $90 \mathrm{a}$ & $12.97 \mathrm{a}$ & $72 \mathrm{a}$ & $31.01 \mathrm{~b}$ & $34.09 \mathrm{~b}$ & $31.55 \mathrm{~b}$ & $3.40 \mathrm{c}$ \\
$-0.5 \mathrm{MPa} \rightarrow$ Inactive SNP & $86 \mathrm{~b}$ & $12.39 \mathrm{~b}$ & $67 \mathrm{a}$ & $29.76 \mathrm{~b}$ & $36.76 \mathrm{~b}$ & $36.73 \mathrm{a}$ & $3.98 \mathrm{~b}$ \\
$\mathrm{SNP}$ & $86 \mathrm{~b}$ & $6.64 \mathrm{c}$ & $62 \mathrm{a}$ & $35.66 \mathrm{a}$ & $34.91 \mathrm{~b}$ & $28.81 \mathrm{~b}$ & $3.62 \mathrm{c}$ \\
Ferrocyanide & $89 \mathrm{a}$ & $7.28 \mathrm{c}$ & $72 \mathrm{a}$ & $36.26 \mathrm{a}$ & $36.69 \mathrm{~b}$ & $30.41 \mathrm{~b}$ & $4.02 \mathrm{~b}$ \\
Inactive SNP & $96 \mathrm{a}$ & $14.21 \mathrm{a}$ & $67 \mathrm{a}$ & $37.02 \mathrm{a}$ & $43.03 \mathrm{a}$ & $31.56 \mathrm{~b}$ & $4.43 \mathrm{a}$ \\
$\mathrm{Control}($ water) & $89 \mathrm{a}$ & $13.58 \mathrm{a}$ & $70 \mathrm{a}$ & $34.74 \mathrm{a}$ & $41.30 \mathrm{a}$ & $34.80 \mathrm{a}$ & $4.56 \mathrm{a}$ \\
$-0.3 \mathrm{MPa}$ & $67 \mathrm{c}$ & $7.06 \mathrm{c}$ & $8 \mathrm{~b}$ & $8.91 \mathrm{~d}$ & $25.04 \mathrm{~d}$ & $25.38 \mathrm{c}$ & $2.05 \mathrm{~d}$ \\
$-0.4 \mathrm{MPa}$ & $55 \mathrm{~d}$ & $4.95 \mathrm{~d}$ & $0 \mathrm{~b}$ & $0.00 \mathrm{e}$ & $0.00 \mathrm{e}$ & $0.00 \mathrm{~d}$ & $0.00 \mathrm{e}$ \\
$-0.5 \mathrm{MPa}$ & $36 \mathrm{e}$ & $2.91 \mathrm{e}$ & $0 \mathrm{~b}$ & $0.00 \mathrm{e}$ & $0.00 \mathrm{e}$ & $0.00 \mathrm{~d}$ & $0.00 \mathrm{e}$ \\
\hline \multicolumn{1}{c}{$\mathrm{CV}(\%)$} & 5.42 & 7.52 & 12.50 & 8.62 & 8.66 & 7.07 & 7.20
\end{tabular}

Mean values followed by the same letters do not differ among themselves in the Scott-Knott test at $5 \%$ probability. CV: coefficient of variation. 
There was an increase in shoot and root length and in shoot and root dry matter in all the treatments with soaking in salt solution followed by transfer to SNP, inactive SNP, and ferrocyanide in comparison to the respective pure salt stresses (Table 2).

The treatments with water, SNP, ferrocyanide, and inactive SNP together with the respective salt stresses $(-0.3$, -0.4 , and $-0.5 \mathrm{MPa}$ ) showed the greatest effect of the SNP, ferrocyanide, and inactive SNP. As expected, there was a decline in germination in all the treatments with an increase in salt stress, considering that under these conditions, there is a tendency to reduction in germination even in the treatments with SNP, inactive SNP, and ferrocyanide, where there was recovery of germination (Table 3 ).

The highest percentages of germination were obtained in the treatment with inactive SNP together with the salt stresses of -0.3 and $-0.4 \mathrm{MPa}(93 \%$ and $89 \%$, respectively). These germination percentages were $39 \%$ and $62 \%$ higher than the germination percentages under pure salt stress of -0.3 (of $67 \%$ ) and $-0.4 \mathrm{MPa}$ (of 55\%), respectively (Table 3 ).

At the potential of $-0.5 \mathrm{MPa}$, germination increased in all the solutions (SNP, inactive SNP, and ferrocyanide) in relation to pure salt stress $(0.5 \mathrm{MPa})$. In the treatments with $-0.5 \mathrm{MPa}$ together with the inactive SNP and SNP solutions, an $81 \%$ increase in germination was observed, while together with ferrocyanide, a $92 \%$ increase was observed, in relation to germination under pure salt stress $(-0.5 \mathrm{MPa})$. Nevertheless, between the inactive SNP and SNP solutions, there was no significant difference (Table 3).

The percentage of normal seedlings at the osmotic potential of $-0.3 \mathrm{MPa}$ was greater in the treatments in combination with any one of the solutions. In the treatment with osmotic potential of $-0.3 \mathrm{MPa}$ together with ferrocyanide, there was a greater percentage of normal seedlings, exhibiting a $463 \%$ increase in relation to pure salt stress, which was statistically different from the treatments together with SNP and inactive SNP. At the osmotic potential of - $0.3 \mathrm{MPa}$ together with SNP and inactive SNP, there was a $300 \%$ and $250 \%$ increase, respectively, in formation of normal seedlings, which was significantly different from pure salt stress. However, they did not differ significantly between themselves. There was formation of normal seedlings at the osmotic potential of $-0.4 \mathrm{MPa}$ when the seeds were soaked in ferrocyanide $(22 \%)$ and inactive SNP $(7 \%)$ solution. However, only the combined treatment of ferrocyanide with -0.4 MPa differed statistically from the control.

The lengths of the shoots in all the treatments together with salt stress of -0.3 MPa did not differ among themselves (Table 3). For the osmotic potential of $-0.4 \mathrm{MPa}$, the parameters of shoot and root system length, and shoot and root dry matter, were only observed in the treatments in combination with ferrocyanide and inactive SNP.

Table 3. Germination (G) (\%), germination speed index (GSI), normal seedlings (NS) (\%), shoot length (SL) (mm), root length (RL) (mm), shoot dry matter (SDM) (mg), and root dry matter (RDM) (mg) in scarified seeds of $S$. macranthera placed to germinate in different treatments (SNP, inactive SNP, and ferrocyanide) together with salt stress $(-0.3,-0.4$, and $-0.5 \mathrm{MPa}$ ) at $25^{\circ} \mathrm{C}$.

\begin{tabular}{|c|c|c|c|c|c|c|c|}
\hline Treatment & G & GSI & NS & SL & RL & SDM & RDM \\
\hline $\mathrm{H}_{2} \mathrm{O}+-0.3 \mathrm{MPa}$ & $6 \mathrm{c}$ & $7.06 \mathrm{~d}$ & $8 \mathrm{~d}$ & $8.91 \mathrm{~b}$ & $25.04 \mathrm{~d}$ & $25.38 \mathrm{~d}$ & $2.05 \mathrm{e}$ \\
\hline $\mathrm{H}_{2} \mathrm{O}+-0.4 \mathrm{MPa}$ & $55 \mathrm{~d}$ & $4.95 \mathrm{f}$ & $0 \mathrm{~d}$ & $0.00 \mathrm{c}$ & $0.00 \mathrm{f}$ & $0.00 \mathrm{f}$ & $0.00 \mathrm{~g}$ \\
\hline $\mathrm{H}_{2} \mathrm{O}+-0.5 \mathrm{MPa}$ & $36 \mathrm{e}$ & $2.91 \mathrm{~h}$ & $0 \mathrm{~d}$ & $0.00 \mathrm{c}$ & $0.00 \mathrm{f}$ & $0.00 \mathrm{f}$ & $0.00 \mathrm{~g}$ \\
\hline $\mathrm{SNP}+-0.3 \mathrm{MPa}$ & $82 \mathrm{~b}$ & $4.46 \mathrm{f}$ & $32 \mathrm{c}$ & $11.06 \mathrm{~b}$ & $22.54 \mathrm{e}$ & $14.33 \mathrm{e}$ & $1.47 \mathrm{f}$ \\
\hline $\mathrm{SNP}+-0.4 \mathrm{MPa}$ & $70 \mathrm{c}$ & $3.08 \mathrm{~h}$ & $0 \mathrm{~d}$ & $0.00 \mathrm{c}$ & $0.00 \mathrm{f}$ & $0.00 \mathrm{f}$ & $0.00 \mathrm{~g}$ \\
\hline $\mathrm{SNP}+-0.5 \mathrm{MPa}$ & $65 \mathrm{c}$ & $5.76 \mathrm{e}$ & $0 \mathrm{~d}$ & $0.00 \mathrm{c}$ & $0.00 \mathrm{f}$ & $0.00 \mathrm{f}$ & $0.00 \mathrm{~g}$ \\
\hline Ferrocyanide $+-0.3 \mathrm{MPa}$ & $87 \mathrm{~b}$ & $4.70 \mathrm{f}$ & $45 \mathrm{~b}$ & $12.76 \mathrm{~b}$ & $24.96 \mathrm{~d}$ & $16.52 \mathrm{e}$ & $1.80 \mathrm{e}$ \\
\hline Ferrocyanide $+-0.4 \mathrm{MPa}$ & $66 \mathrm{c}$ & $3.83 \mathrm{~g}$ & $22 \mathrm{c}$ & $10.32 \mathrm{~b}$ & $20.41 \mathrm{e}$ & $15.33 \mathrm{e}$ & $1.44 \mathrm{f}$ \\
\hline Ferrocyanide $+-0.5 \mathrm{MPa}$ & $69 \mathrm{c}$ & $6.09 \mathrm{e}$ & $0 \mathrm{~d}$ & $0.00 \mathrm{c}$ & $0.00 \mathrm{f}$ & $0.00 \mathrm{f}$ & $0.00 \mathrm{~g}$ \\
\hline Inactive $\mathrm{SNP}+-0.3 \mathrm{MPa}$ & $93 \mathrm{a}$ & $10.91 \mathrm{~b}$ & $28 \mathrm{c}$ & $12.37 \mathrm{~b}$ & $28.80 \mathrm{c}$ & $30.97 \mathrm{~b}$ & $3.65 \mathrm{c}$ \\
\hline Inactive SNP+ - 0.4MPa & $89 \mathrm{~b}$ & $9.11 \mathrm{c}$ & $7 \mathrm{~d}$ & $10.88 \mathrm{~b}$ & $24.43 \mathrm{~d}$ & $31.48 \mathrm{~b}$ & $3.32 \mathrm{~d}$ \\
\hline Inactive SNP+ - 0.5MPa & $65 \mathrm{c}$ & $5.59 \mathrm{e}$ & $0 \mathrm{~d}$ & $0.00 \mathrm{c}$ & $0.00 \mathrm{f}$ & $0.00 \mathrm{f}$ & $0.00 \mathrm{~g}$ \\
\hline SNP & $86 \mathrm{~b}$ & $6.64 \mathrm{~d}$ & $62 \mathrm{a}$ & $35.66 \mathrm{a}$ & $34.91 \mathrm{~b}$ & $28.81 \mathrm{c}$ & $3.62 \mathrm{c}$ \\
\hline Ferrocyanide & $89 \mathrm{~b}$ & $7.28 \mathrm{~d}$ & $72 \mathrm{a}$ & $36.26 \mathrm{a}$ & $36.69 \mathrm{~b}$ & $30.41 \mathrm{~b}$ & $4.02 \mathrm{~b}$ \\
\hline Inactive SNP & $96 \mathrm{a}$ & $14.21 \mathrm{a}$ & $67 \mathrm{a}$ & $37.02 \mathrm{a}$ & $43.03 \mathrm{a}$ & $31.56 \mathrm{~b}$ & $4.43 \mathrm{a}$ \\
\hline Control (water) & $89 \mathrm{~b}$ & $13.58 \mathrm{a}$ & $70 \mathrm{a}$ & $34.74 \mathrm{a}$ & $41.30 \mathrm{a}$ & $34.80 \mathrm{a}$ & $4.68 \mathrm{a}$ \\
\hline $\mathrm{CV}(\%)$ & 5.45 & 7.52 & 24.47 & 15.19 & 11.48 & 10.52 & 11.75 \\
\hline
\end{tabular}

Mean values followed by the same letters do not differ among themselves by the Scott-Knott test at $5 \%$ probability. CV: coefficient of variation. 
The NO directly participates in physiological functions such as seed germination, root formation, and defense mechanisms (He et al., 2013). Similar to this study, the effect of $\mathrm{NO}$ on the increase in germination was found in Lupinus luteus (Kopyra and Gwóz'dz', 2003), Cucumis sativus (Fan et al., 2013), and Ocimum basilicum (Saeidnejad et al., 2013) seeds, in which SNP was effective in reversing the deleterious effects of excess of salts.

However, effects similar to those brought about by the treatment with SNP were also found in the treatments with inactive SNP and ferrocyanide, indicating that they were related to release of the cyanide in the SNP and not to nitric oxide. These results suggest that SNP improves germination under salt stress conditions through release of cyanide, and the application of either SNP or ferrocyanide is possible as a tool for increasing the germination of the seeds of this species under salt stress conditions.

As observed, salt stress at the potentials of $-0.3,-0.4$, and $-0.5 \mathrm{MPa}$ adversely affects the germination and development of $S$. macranthera seedlings. In addition to the osmotic effect that prevents water absorption by seeds, excess of salts can generate an accumulation of ions during the germination process, causing physiological and biochemical disturbances, such as hormonal imbalance and reduced use of reserves (Yacoubi et al., 2013).

Although cyanide is a compound that inhibits the respiratory process, it is naturally formed in plants as the by product of ethylene biosynthesis and, at low concentrations, can bring beneficial effects, such as mobilization of sucrose and starch in breaking dormancy in seeds and stimulating germination (Molojwane et al., 2015; Gerivani et al., 2016).

The highest values of GSI found in this study were in seeds soaked in inactive SNP solution followed by transfer to salt stresses. In Plathymenia reticulata seeds, the highest values of germination speed indexes were observed in seeds pre-soaked in SNP solution for 24 hours at the concentration of $100 \mu \mathrm{M}$ (Pereira et al., 2010).

Amaranthus albus and Lactuca sativa seeds are among the few reports on some nitric oxide donors and evaluation of the individual effect of the compounds that may cause beneficial effects. For these seeds, there was an increase in germination in potassium cyanide $(\mathrm{KCN})$ solutions at low concentrations (Hendricks and Taylorson, 1972).

For Panicum virgatum seeds, germination increased significantly with the application of ferrocyanide and potassium ferrocyanide. After two days of soaking, the increase in germination was $200 \%$ greater compared to the control treatment (water) (Sarath et al., 2006). The authors also evaluated the effect of the nitric oxide scavenger (PTIO), which reduced seed germination. It was understood to reverse the stimulant effect of these substances. Based on these results, this scavenger would not be an effective confirmation test to confirm the effect of which compound would be active.

According to Sarath et al. (2006), cyanide may induce the production of nitric oxide during seed germination and it, in turn, targets proteins that favor lengthening (radicle emergence) and cell growth (extension of coleoptiles).

A pioneering study with Clitoria ternatea and Rhyncosia minima showed that cyanide increased germination of the seeds of the two species in relation to the treatment without application of cyanide (Mullick and Chatterji, 1967). Egley and Duke (1985) suggested that one of the possible effects caused by cyanide would be making $\mathrm{O}_{2}$ available to the oxidative pathway of the phosphate pentoses. In this pathway, there is production of erythrose-4-phosphate, which upon being redirected to secondary metabolism enters in the shikimic acid pathway, leading to synthesis of growth regulators that affect germination (Taiz and Zeiger, 2017).

In another study using SNP to break dormancy of Arabidopsis seeds, the cyanide present in the solution was also seen as causing this effect (Bethke et al., 2006). The authors reported that the nitric oxide scavenger (cPTIO) used as a confirmation test of the SNP blocked the breaking of dormancy. Oracz et al. (2008) also reported breaking of dormancy in sunflower seeds exposed to cyanide.

Based on the results found for Panicum virgatum (Sarath et al., 2006) and Arabidopsis (Bethke et al., 2006) seeds, in which the nitric oxide scavengers PTIO and cPTIO, respectively, were not effective as confirmation tests, and based on the results found for inactive SNP and ferrocyanide in this study, which exhibited satisfactory effects, these two substances can be recommended as controls of the SNP effect.

For the species Clitoria ternatea and Rhyncosia minima, germination and initial growth of the seedlings are accelerated with cyanide at the concentration of $100 \mathrm{ppm}$ (Mullick and Chatterji, 1967). According to the authors, the best result was obtained by immersion of the seeds for 24 hours in $100 \mathrm{ppm}$ of sodium cyanide, and they emphasized that high concentrations of cyanide inhibit seed germination.

\section{Conclusions}

The treatments that proved to be more promising in recovery of germination under salt stress are $-0.4 \mathrm{MPa}$ together with SNP; -0.4 MPa together with inactive SNP; -0.5 MPa together with SNP and -0.5 MPa together with inactive SNP. Based on all the results, it can be concluded that SNP improves the germination of Senna macranthera under salt 
stress conditions, through release of cyanide. To achieve such effects, application of ferrocyanide is also possible.

\section{Acknowledgments}

Our thanks to the Conselho Nacional de Desenvolvimento Científico e Tecnológico (CNPq) and to the Fundação de Amparo à Pesquisa de Minas Gerais (FAPEMIG).

\section{References}

AHMAD, P.; ABDEL LATEF, A.A.; HASHEM, A.; ABD_ALLAH, E.F.; GUCEL, S.; TRAN, L.S.P. Nitric oxide mitigates salt stress by regulating levels of osmolytes and antioxidant enzymes in Chickpea. Frontiers in Plant Science, v.7, p.347, 2016. https://www. ncbi.nlm.nih.gov/pmc/articles/PMC4814448/

BETHKE, P.C.; LIBOUREL, I.G.L.; JONES, R.L. Nitric oxide reduces seed dormancy in Arabidopsis. Journal of Experimental Botany, v.57, n.3, p.517-526, 2006. https://academic.oup.com/jxb/ article $/ 57 / 3 / 517 / 510715$

BEWLEY, J.D.; BRADFORD, K.J.; HENK, W.M.; NONOGAKI, H. Seeds: Physiology of Development, Germination and Dormancy, 3rd ed. New York: Springer Science + Business Media, 2013.407p.

DUSSE, L.M.S.; VIEIRA, L.M.; CARVALHO, M.G. Revisão sobre óxido nítrico. Jornal Brasileiro de Patologia e Medicina Laboratorial, v.39, p.343-350, 2003. http://www.scielo.br/pdf/ jbpml/v39n4/18548.pdf

EGLEY, G.H.; DUKE, S. Physiology of weed seed dormancy and germination. In: DUKE, S. O. Weed physiology. I. Reproduction and ecophysiology. Boca Raton: CRC Press, 1985. p.27-64.

FAN, H.F.; DU, C.X.; DING, L.; XU, Y.L. Effects of nitric oxide on the germination of cucumber seeds and antioxidant enzymes under salinity stress. Acta Physiology Plant, v.35, p.2707-2719, 2013. http://link.springer.com/article/10.1007\%2Fs11738-013-1303-0\#

GERIVANI, Z.; VASHAEE, E.; SADEGHIPOUR, H.R.; AGHDASI, M.; SHOBBAR, Z.S.; AZIMMOHSENI, M. Short versus long term effects of cyanide on sugar metabolism and transport in dormant walnut kernels. Plant Science, v.252, p.193-204, 2016. https://www. ncbi.nlm.nih.gov/pubmed/27717454

HE, J.M.; MA, X.G.; ZHANG, Y.; SUN, T.F.; XU, F.F.; CHEN, Y.P.; LIU, X.; YUE, M. Role and interrelationship of G $\alpha$ protein, hydrogen peroxide, and nitric oxide in ultraviolet-B-induced stomatal closure in Arabidopsis leaves. Plant Physiology, v.161, p.1570-1583, 2013. https://www.ncbi.nlm.nih.gov/pubmed/23341360

HENDRICKS, S.B.; TAYLORSON, R.B. Promotion of seed germination by nitrates and cyanides. Nature, v.237, p.169-170, 1972. http://www.nature.com/articles/237169b0

KAYA, C.; ASHRAF, M.; SÖNMEZ, O.; TUNA, A. L.; AYDEMIR, S. Exogenously applied nitric oxide confers tolerance to salinity-induced oxidative stress in two maize (Zea mays L.) cultivars differing in salinity tolerance. Turkish Journal of Agriculture and Forestry, v.39, n.6, p.909919, 2015. http://dergipark.gov.tr/download/article-file/120883
KHAN, M.N.; SIDDIQUI, M.H.; MOHAMMAD, F.; NAEEM, M. Interactive role of nitric oxide and calcium chloride in enhancing tolerance to salt stress. Nitric Oxide, v.27,n.4, p.210-218, 2012. https://www.ncbi.nlm.nih.gov/pubmed/22884961

KOPYRA, M.; GWÓZ'DZ', E.A. Nitric oxide stimulates seed germination and counteracts the inhibitory effect of heavy metals and salinity on root growth of Lupinus luteus. Plant Physiology Biochemistry, v.41, p.1011-1017, 2003. http://www.sciencedirect. com/science/article/pii/S098194280300175X

LONG, R.L.; GORECKI, M.J.; RENTON, M.; SCOTT, J.K.; COLVILlE, L.; GOGGIN, D.E.; FINCH-SAVAGE, W.E. The ecophysiology of seed persistence: a mechanistic view of the journey to germination or demise. Biological Reviews, v.90, n.1, p.31-59, 2015. http://www.ncbi.nlm.nih.gov/pubmed/24618017

LORENZI, H. Árvores Brasileiras: Manual de Identificação e Cultivo de Plantas Arbóreas Nativas do Brasil. 3. ed., Nova Odesssa, SP: Instituto Plantarum de Estudos da Flora Ltda, 2000. 352p.

LIN, Y.; YANG, L.; PAUL, M.; ZU, Y.; TANG, Z. Ethylene promotes germination of Arabidopsis seed under salinity by decreasing reactive oxygen species: evidence for the involvement of nitric oxide simulated by sodium nitroprusside. Plant Physiology and Biochemistry, v.73, p.211-218, 2013. http://europepmc.org/abstract/ $\operatorname{med} / 24148906$

MOLOJWANE, E.; ADAMS, N.; SWEETLOVE, L.J.; INGLE, R.A. Heterologous expression of mitochondria-targeted microbial nitrilase enzymes increases cyanide tolerance in Arabidopsis. Plant Biology, v.17, n.4, p.922-926, 2015. http://onlinelibrary.wiley.com/ doi/10.1111/plb.12323/full

MOSTOFA, M.G.; FUJITA, M.; TRAN, L.S.P. Nitric oxide mediates hydrogen peroxide-and salicylic acid-induced salt tolerance in rice (Oryza sativa L.) seedlings. Plant Growth Regulation, v.77, n.3, p.265-277, 2015. http://link.springer.com/article/10.1007/s10725015-0061-y

MULLICK, P.; CHATTERJI, U.N. Effect of Sodium Cyanide on germination of two leguminous seeds. Österreichische botanische Zeitschrift, v.114, n.1, p.88-91, 1967. https://www.jstor.org/stable/ i40132568

ORACZ, K.; EL-MAAROUF-BOUTEAU, H.; BOGATEK, R.; CORBINEAU, F.; BAILLY, C. Release of sunflower seed dormancy by cyanide: cross-talk with ethylene signalling pathway. Journal of Experimental Botany, v.59, n.8, p.2241-2251, 2008. https://www. ncbi.nlm.nih.gov/pmc/articles/PMC2413275/

PEREIRA, B.L.C.; BORGES, E.E.L.; OLIVEIRA, A.C.; LEITE, H.G.; GONÇALVES, J.F.C. Influência do óxido nítrico na germinação de sementes de Plathymenia reticulata Benth com baixo vigor. Scientia Florestalis, v.38, n.88, p.629-636, 2010. http://www. ipef.br/publicacoes/scientia/nr88/cap09.pdf

SAEIDNEJAD, A.H.; PASANDI-POUR, A.; PAKGOHAR, N.; FARAHBAKHSH, H. Effects of exogenous nitric oxide on germination and physiological properties of basil under salinity stress. Journal of Medicinal Plants and By-products, v.1, p.103-113, 2013. http://www.academia.edu/9493044/Effects_of_Exogenous Nitric_Oxide_on_Germination_and_Physiological_Properties_of_Basil_under_Salinity_Stress 
SANTNER, A.; ESTELLE, M. Recent advances and emerging trends in plant hormone signaling. Nature, v.459, p.1071-1078, 2009. https://www.ncbi.nlm.nih.gov/pubmed/19553990

SARATH, G.; BETHKE, P.C.; JONES, R.; BAIRD, L.M.; HOU, G.; MITCHELL, R.B. Nitric oxide accelerates seed germination in warm-season grasses. Planta, v.223, n.6, p.1154-1164, 2006. http:// europepmc.org/abstract/MED/16369800

SILVA, A.L.; DIAS, D.C.F.S.; BORGES, E.E.L.; RIBEIRO, D.M.; SILVA, L.J. Effect of sodium nitroprusside (SNP) on the germination of Senna macranthera seeds (DC. ex Collad.) H. S. Irwin \& Baneby under salt stress. Journal of Seed Science, v.37, n.4, p.236-243, 2015. http://www.scielo.br/scielo.php?script=sci arttext\&pid=S2317-15372015000400236

SIMAEI, M.; KHAVARI-NEJAD, R.A.; BERNARD, F. Exogenous Application of salicylic acid and nitric oxide on the ionic contents and enzymatic activities in $\mathrm{NaCl}$-stressed soybean plants. American Journal of Plant Sciences, v.3, n.10, p.1495-1503, 2012. http://www. scirp.org/journal/PaperInformation.aspx?PaperID=24169

TAIZ, L.; ZEIGER, E. Fisiologia vegetal e desenvolvimento vegetal. 6nd ed., Porto Alegre: Artmed, 2017. 888p.
WANG, P.G.; XIAN, M.; TANG, X.; WU, X.; WEN, Z.; CAI, T.; JANCZUK, A.J. Nitric oxide donors: Chemical activities and biological applications. Chemical Reviews, v.102, p.1091-1134, 2002. https://www.ncbi.nlm.nih.gov/pubmed/11942788

YACOUBI, R.; JOB, C.; BELGHAZI, M.; CHAIBI, W.; JOB, D. Proteomic analysis of the enhancement of seed vigour in osmoprimed alfalfa seeds germinated under salinity stress. Seed Science Research, v.23, n.2, p.99-110, 2013. https://www. cambridge.org/core/journals/seed-science-research/article/ proteomic-analysis-of-the-enhancement-of-seed-vigour-inosmoprimed-alfalfa-seeds-germinated-under-salinity-stress/ F7B19A09BC78CDF65943DD863C281977

ZHENG, C.; JIANG, D.; LIU, F.; DAI, T.; LIU, W.; JING, Q.; $\mathrm{CAO}, \mathrm{W}$. Exogenous nitric oxide improves seed germination in wheat against mitochondrial oxidative damage induced by high salinity. Environmental and Experimental Botany, v.67, p.222$227,2009 . \quad \mathrm{http} / / / \mathrm{www}$. sciencedirect.com/science/article/pii/ S0098847209000896 